\title{
Soft Skills and their Wage Returns: Overview of Empirical Literature ${ }^{1}$
}

\section{Jiří Balcar ${ }^{2}$}

\begin{abstract}
Psychological traits, attitudes and soft skills represent factors whose effect on an individual's wages has begun to be examined recently. Today, there is an extensive empirical body on wage returns to the first two factors, but still a relatively small one on wage returns to soft skills, such as communication, cooperation, leadership etc. The aim of this paper is to provide an overview of empirical literature on wage returns to soft skills. It suggests that soft skills are connected with significant wage returns and contribute to closing the gender wage gap. The end of the paper focuses on a discussion on methodological approaches to measurement of soft skills and relevancy of their approximation by job characteristics (incl. suggestion of using tools of competency modelling for this purpose).
\end{abstract}

Key words: Soft skills, wage returns, wage gap, skills-job match

JEL classification: J24, J31, J71

\section{Introduction}

There is a large number of factors which have been found to be significant determinants of an individual's wage (for an overview of the most common supply side wage determinants see Balcar, 2012). Psychological traits, attitudes and soft skills represent those whose effect on an individual's wages has begun to be examined recently. Today, there is an extensive empirical body on wage returns to the first two factors, but still a relatively small one on wage returns to soft skills (for instance communication, cooperation or leadership). The aim of this paper is to provide an overview of empirical literature focusing exclusively on soft skills in order to evaluate an influence of soft skills on individual's wage and discuss approaches employed in soft skills measurement.

It is worth stressing that "soft skills" represent a term that is generally known and understood, but yet not precisely defined. This is probably the result of both its usage in business practice, where specification of particular skills is more important than a definition of comprehensive term (thus soft skills are usually defined by enumeration of skills, which can differ among companies), and usage of alternative terms in academic sphere, such as non-cognitive skills, personal skills or people skills (which do not, however, represent a synonym for soft skills). An application of the term "soft skills" in

\footnotetext{
${ }^{1}$ This paper has been funded by a grant from the Czech Science Foundation (grant number P402/11/2464) for a research on the gender wage gap in Czech Republic.

${ }^{2}$ VSB - Technical University of Ostrava, Economic faculty, Sokolská trř́da 33, 70121 Ostrava; balcar.er@gmail.com
} 
this paper represents an attempt to support applicability of results of academic research in practice through unification of the terminology.

The first section of the paper provides a general definition of soft skills (incl. some other relevant terms) and their examples in order to specify the exact focus of this paper. The second one provides conclusions of empirical studies on wage returns to these skills. The overview shows that soft skills are statistically significant determinants of an individual's wage and contribute to closing the gender wage gap. The last section discusses methodological approaches to measurement of soft skills and relevancy of their approximation by job characteristics (incl. suggestion of using tools of competency modelling for this purpose).

\section{Soft skills}

Spreading of a competency approach in human resources management led to focusing on particular skills of workers / job applicants, instead of their IQ or formal level of educational attainment, in processes of hiring, evaluation, development and planning of career growth (Kubeš, Spillerová, Kurnický, 2004). An importance of this trend can be illustrated by many lists of skills necessary for employability and work performance of an individual which are defined at national (or international) level and which became a part of national educational policies (e.g. Basic skills, Core skills, Critical enabling skills, Employability skills, Essential skills, Generic skills or Key skills; see Table 1.2 in Balcar, Homolová, Karásek et al., 2011 for their detailed description), or by effort to identify future skills needs at these levels (e.g. see Balcar, 2011 for information on future skills needs at EU level).

The bulk of skills supporting individual's employability can be found among the so called "soft skills" which can be described as "intangible skills ${ }^{3}$ which are hard to measure and are closely connected with [individual's] attitudes ${ }^{4}$ " (Balcar, Homolová, Karásek et al., 2011), e.g. communication, cooperation, leadership, independence or creativity. "Hard skills", on the other hand, can be described as "skills which are easily observed and/or measured, easily trained and closely connected with [individual's] knowledge $^{6, "}$ (Balcar, Homolová, Karásek et al., 2011), e.g. ICT skills, surgical skills or

\footnotetext{
${ }^{3}$ Skill is "the capacity for carrying out complex, well-organized patterns of behaviour smoothly and adaptively so as to achieve some end or goal" (Reber, Reber, 2001).

${ }^{4}$ Attitude is ,,a stable, long-lasting, learned predisposition to respond to certain things in a certain way" (Statt, 1998).

${ }^{5}$ Classification of soft skills used by the National System of Occupations (NSP, 2011) can further clarify this term (and thus focus of this paper) as it provides definitions of 15 soft skills, including enumeration of their sub-skills, and behavioural descriptions of their levels. (The classification comprehends the following skills: communication, cooperation, creativity, flexibility, consumer orientation, efficiency, independence, problem solving, planning and organizing, life-long learning, proactive approach, stress resiliency, exploring and orientation in information, leadership, and influencing others.) It also suggests that terms "people skills" or "non-cognitive skills", which are often used in present empirical literature, do not represent synonym to "soft skills". It is given by the fact that soft skills are not limited only to skills necessary for interpersonal interactions and are closely connected to individual's cognitive skills. ${ }^{6}$ Knowledge is "the body of information possessed by a person, by a group of persons or a culture" (Reber, Reber, 2001).
} 
typing skills. It can be added that hard skills, compared to soft skills, are more closely related to formal qualification of an individual.

The importance of soft skills has increased significantly in the last few decades. For example, Borghans, Weel and Weinberg (2006) reported a substantial growth in the number of people performing job tasks requiring soft skills from 1970 to 2002. However, Weinberger (2011) found that the growth of employment is concentrated mainly in jobs requiring a combination of both cognitive and soft skills, whereas employment in jobs requiring either cognitive or soft skills was relatively stable from 1977 to 2010. It corresponds to the findings of Bacolod and Blum (2008), who found a statistically significant correlation between requirements on cognitive and soft skills which showed that they complement each other. An indirect evidence of the growing importance of soft skills was presented by Bacolod and Blum (2008) who found out that the wage premium to soft skills doubled during the period 1968 - 1990.

Although there is a wide consensus on the positive role of soft skills on individual's employability and other labour market outcomes, there is still a relatively small (but growing) empirical body on wage returns to this kind of human capital (as was pointed out also by Borghans, Weel, Weinberg, 2006 and 2008) ${ }^{7}$. Since the aim of this paper is to provide an overview of empirical literature focused exclusively on soft skills (according to above stated definition), the rapidly growing literature on wage returns to various psychological traits and attitudes is not taken into account. (However, it should be noted that soft skills are significantly influenced by individual's psychological traits and attitudes which make their precise distinction difficult.)

\section{Overview of empirical literature on wage returns to soft skills}

Wage returns to specific clusters of soft skills, communication skills, leadership skills and attitudes closely related to particular soft skills are discussed in the following paragraphs (detailed information on reviewed papers can be found in Table 1).

Borghans, Weel and Weinberg (2006) estimated wage returns to a whole range of soft skills, presence of which was approximated by importance of "people tasks" for job performance. They also examined whether or not individual's sociability (measured during childhood and early adulthood) is associated with wage premium in jobs where people tasks are important. Results showed that individuals working in jobs where people tasks are important face lower wages. The wage penalty connected with a standard deviation increase in the importance of people tasks was estimated at circa 5\% in the U.S. and 4-9\% in UK. The sociability variables, though not all, indicated a very low wage premium in those jobs (circa 1\%).

Bacolod and Blum (2008), who focused on wage returns to people skills, cognitive skills and motor skills, used a description of job tasks and requirements from Dictionary of Occupational Titles to define these variables. They found out that wage returns to

\footnotetext{
${ }^{7}$ It can be noted that socioeconomic outcomes of soft skills are not entirely new topic in economics. It is possible to identify some older empirical papers on this theme, although they are rare. For instance, Turner and Martinez (1977) discussed effects of individual's manipulativeness on family income and occupational prestige among men. They found out that it represents an important determinant of income and occupational prestige for men with higher education, but not for less educated men.
} 
people skills nearly doubled in the period from 1968 to 1990 (one standard deviation increase in people skills was associated with 3.2\% wage increase in 1968 and $6.0 \%$ increase in 1990), while returns to cognitive skills increased "only" by $60 \%$ and returns to motor skills decreased by $50 \%$. A detailed examination revealed that people skills have no value themselves, but only as a complement to other skills. The growth of wage returns to people skills was, in fact, caused by increasing returns to combination of cognitive (or motor) and people skills in the period from 1968 to 1990. This also corresponds to the findings of Weinberger (2011) who identified significant growth of employment only in jobs requiring both cognitive and people (in this case leadership) skills.

Black and Spitz-Oener (2007) examined gender differences in wage returns to a broad range of skills approximated by different job tasks. The tasks were identified on the basis of Qualification and Career Survey, where employees reported their job tasks. Authors defined five groups of skills: non-routine interactive tasks, non-routine analytic tasks, routine cognitive tasks, routine manual tasks and non-routine manual tasks, where the designation "routine tasks" suggests possibility of machine processing. Their estimation showed that wage premium is connected (in descending order) with nonroutine interactive tasks, non-routine analytic tasks and routine cognitive tasks, whereas wage penalty is connected with routine manual tasks and non-routine manual tasks.

Borghans, Weel and Weinberg (2008) applied a novel approach to the examination of wage returns to soft skills by focusing on an interpersonal interaction approximated by a trade-off between directness, which facilitates accurate communication, and caring, which establishes a cooperative environment. Results revealed that one standard deviation increase in directness relative to caring raised wages by $9.6 \%$ in 1997 and $10.8 \%$ in 2001 in UK, and by $3.8 \%$ in 1979 and $10.2 \%$ in 1998 in Germany. It means that a statistically significant increase of returns to directness was identified during the examined period in both countries. It should be also mentioned that the premium for directness was higher in occupations, where it is more important.

Another unusual approach was employed by Conti, Galeotti, Mueller and Pudney (2009), who used popularity (defined as number of classmates who consider a particular person to be a friend) as a proxy for the ability to make positive personal and social adjustments (or more precisely ability to understand "the rules of the game", gain acceptance and social support from colleagues, and distinguish whom to trust and when to reciprocate). They found out that one additional friendship nomination of the person in high school is associated with $35 \%$ wage premium 35 years later, which corresponds to $40 \%$ of one more year of education.

Kuhn and Weinberger (2005) focused on wage returns to leadership skills in case of white men. These skills were measured by observable leadership activities of an individual during his study at high school and by their self-assessment. These leadership variables were regressed on annual and hourly earnings 9-13 years later (depending on a dataset used). Estimations showed that men, who were both a captain of an athletic team and a president of a club or other organization at high school, earn 3.8-22.1\% more than others. The same pattern was identified for self-assessed leadership skills as well. Authors also proved that individuals who acted in any leadership role (i.e. captain, president, or both) have a higher probability of occupying a managerial job in the future. 
In one of his later papers, Weinberger (2011) brought new evidence on wage returns to leadership skills. She used behavioural indicator of leadership again and regressed it on weekly earnings 7 years after graduation. Results confirmed a statistically significant $5.3 \%$ wage premium for leadership skills, or more precisely, for leadership in clubs, performing arts and student publications or sport participation, which more than doubled between 1979 and 1999. The growth of wage premium differed according to the complexity of work, i.e. was growing in occupations requiring high levels of both social and cognitive skill, fairly constant in occupations requiring high levels of either social or cognitive skill (but not both) and falling in occupations with low skills requirements.

For an illustration, it is also possible to briefly mention some papers focusing on psychological traits and preferences closely related to particular soft skills. Fortin (2008) tried to capture personal motivation and work effort through an importance of money and work for an individual. He showed that the importance of money/work is a statistically significant predictor of wage level, and that its effect grows over time. Dunifon and Duncan (1998) estimated effects of personal efficacy, defined as an ability to reach long-term goals through individual's intentional activities, on wages of men. They found out that one standard deviation increase in personal efficacy measured during years $1968-1972$ is associated with a $14 \%$ wage premium in 1988-1992. A need for challenge (i.e. getting ahead) relative to affiliation (i.e. getting along) measured in 1972 was identified as another significant determinant of wage, because one standard deviation increase of this ratio led to $7 \%$ wage growth in 1988-1992. The wage effect of the need for challenge relative to affiliation was explored also by Semykina and Linz (2007), who found $2.9 \%$ wage premium for one standard deviation increase of this variable (but not statistically significant for men). They also examined wage returns to internal relative to external locus of control as an approximation of individual's initiative, which were estimated at the level of $7.9 \%$ for one standard deviation change of this variable. Statistical significance of locus of control on wage was confirmed also by Andrisani (1977) who found out that e.g. white men of age 16-26 who were ,slightly internal" have enjoyed a $12 \%$ wage premium over men who were "slightly external" (corresponding wage premium for white men of age $48-62$ was $8 \%)^{8}$

\footnotetext{
${ }^{8}$ It is also possible to mention a study of Machin, McIntosh, Vignoles and Viitanen (2001) who used wide range of variables describing behaviour and psychological traits of individuals at the age of 16 to control an influence of these factors on relationship between individual's verbal and math abilities and his/her real hourly wage at the age of 33. Unfortunately, an interpretation of the effect of particular "soft" variables on hourly wage is complicated by duplicities in variables caused by the fact that the same personal trait is often described by more variables or/and the same variable is assessed by more than one subject (self-assessment, parents, teacher). Moreover, the design of variables also affects their statistical significance. However, the estimates showed that at least being on own, timid and cautious at age 16 lead to lower hourly wage of men at age 33 , and having no plans for the future at age 16 decrease hourly wage of women (these results are valid for estimates controlling for qualification level, verbal and math abilities at age 7 and 16, type of school, family background, parental occupations, parental interest and region).
} 
Table 1: Overview of studies on wage returns to soft skills

\begin{tabular}{|c|c|c|c|}
\hline Study & $\begin{array}{c}\text { Borghans, Weel, Weinberg } \\
(2006)\end{array}$ & $\begin{array}{c}\text { Bacolod, Blum } \\
(2008)\end{array}$ & Black, Spitz-Oener (2007) \\
\hline $\begin{array}{c}\text { Soft skill } \\
\text { variable(s) }\end{array}$ & $\begin{array}{l}\text { Importance of people tasks } \\
\text { I) } \\
\text { (binary variable for the USA } \\
\text { and five-point scale for UK) } \\
\text { Sociability } \\
\text { (self-assessment for the USA } \\
\text { and behavioural description } \\
\text { for UK; sociability during } \\
\text { childhood and early } \\
\text { adulthood) }\end{array}$ & $\begin{array}{l}\text { People skills } \\
\text { index }\end{array}$ & $\begin{array}{l}\text { Non-routine interactive tasks } \\
\text { (number of tasks performed by } \\
\text { worker divided by total number of } \\
\text { tasks in the category in \%) } \\
\text { Non-routine analytic tasks } \\
\text { (number of tasks performed by } \\
\text { worker divided by total number of } \\
\text { tasks in the category in \%) }\end{array}$ \\
\hline Data & $\begin{array}{l}\text { Dictionary of Occupational } \\
\text { Titles } 1977 \text { and } 1991 \\
\text { (USA), British Skill Survey } \\
1997 \text { and } 2001 \text { (UK) } \\
\text { National Longitudinal Study } \\
\text { of Youth } 1979 \text { (USA), } \\
\text { British Cohort Study } 1970 \\
\text { (UK) }\end{array}$ & $\begin{array}{l}\text { Dictionary of } \\
\text { Occupational } \\
\text { Titles, Current } \\
\text { Population } \\
\text { Survey 1968- } \\
\text { 1990; employed } \\
\text { individuals aged } \\
\text { 18-64 (USA) }\end{array}$ & $\begin{array}{l}\text { Qualification and Career Survey } \\
1979 \text { and } 1999 \text { (self-report of job } \\
\text { tasks), Administrative Social } \\
\text { Security Records; full-time } \\
\text { employees 22-55 years old without } \\
\text { university or technical college } \\
\text { degree only (West Germany) }\end{array}$ \\
\hline $\begin{array}{c}\text { Dependent } \\
\text { variable }\end{array}$ & $\begin{array}{l}\text { Log of wage } \\
\text { at adulthood }\end{array}$ & $\begin{array}{l}\text { Log of weekly } \\
\text { earnings }\end{array}$ & Log of daily wage \\
\hline Results & $\begin{array}{l}\text { One standard deviation } \\
\text { increase in the importance of } \\
\text { people tasks was associated } \\
\text { with } \\
\text { c. } 5 \% \text { wage penalty in USA } \\
\text { (coefficients from } \\
-0.018 \text { to }-0.021 \text { ) and } 4-9 \% \\
\text { wage penalty in UK } \\
\text { (coefficients from - } 0.010 \text { to - } \\
0.021 \text { ). } \\
\text { One standard deviation } \\
\text { increase in the sociability } \\
\text { was associated with small } \\
\text { wage premium, } \\
\text { c. } 1 \% \text { (coefficients from } \\
0.002 \text { to } 0.005 \text { for both } \\
\text { countries) }\end{array}$ & $\begin{array}{l}\text { One standard } \\
\text { deviation increase } \\
\text { in people skills } \\
\text { was associated } \\
\text { with } 3.2 \% \text { wage } \\
\text { increase in } 1968 \\
\text { and } 6.0 \% \text { wage } \\
\text { increase in } 1990 .\end{array}$ & $\begin{array}{l}\text { Wage returns to non-routine } \\
\text { interactive tasks and non-routine } \\
\text { analytic tasks were found positive } \\
\text { and statistically significant } \\
\text { (regression coefficients } 0.593 \text { and } \\
0.383 \text {, respectively). Wage premium } \\
\text { was higher for women in both cases } \\
\text { (coefficient } 0.85 \text { for interactive tasks } \\
\text { and } 0.838 \text { for analytical tasks). }\end{array}$ \\
\hline $\begin{array}{c}\text { Other } \\
\text { regressors }\end{array}$ & $\begin{array}{l}\text { Individual dummy variables, } \\
\text { year dummy variables, } \\
\text { education, experience, } \\
\text { experience squared, } \\
\text { occupation random effects } \\
\text { (USA) } \\
\text { Education, gender dummy, } \\
\text { experience, experience } \\
\text { squared, math, reading, } \\
\text { writing, physical strength } \\
\text { and stamina, problem } \\
\text { solving, noticing mistakes, } \\
\text { planning of activities, } \\
\text { knowledge of the } \\
\text { organization, occupation } \\
\text { random effects (UK) }\end{array}$ & $\begin{array}{l}\text { Log of cognitive } \\
\text { skills, log of } \\
\text { motor skills, log } \\
\text { of strength, age, } \\
\text { age squared, } \\
\text { experience, } \\
\text { experience } \\
\text { squared, } \\
\text { experience cubed, } \\
\text { dummy for } \\
\text { female, black, } \\
\text { other non-white } \\
\text { race, SMSA } \\
\text { status, high } \\
\text { school graduate, } \\
\text { college graduate, } \\
\text { region }\end{array}$ & $\begin{array}{l}\text { Routine cognitive tasks, routine } \\
\text { manual tasks, non-routine manual } \\
\text { tasks, education, age, education- } \\
\text { gender interactions, age-gender } \\
\text { interactions, tasks-gender } \\
\text { interactions, industry dummies }\end{array}$ \\
\hline
\end{tabular}




\begin{tabular}{|c|c|c|c|}
\hline Study & $\begin{array}{c}\text { Borghans, Weel, Weinberg } \\
\text { (2008) }\end{array}$ & $\begin{array}{l}\text { Conti, Galeotti, Mueller, Pudney } \\
\text { (2009) }\end{array}$ & $\begin{array}{c}\text { Kuhn, Weinberger } \\
\text { (2005) }\end{array}$ \\
\hline $\begin{array}{c}\text { Soft skill } \\
\text { variable(s) }\end{array}$ & $\begin{array}{l}\text { Interpersonal interaction } \\
(\text { directness relative to caring) }\end{array}$ & $\begin{array}{l}\text { Popularity } \\
\text { (number of high school classmates } \\
\text { who consider a particular person } \\
\text { to be a friend) }\end{array}$ & $\begin{array}{l}\text { Leadership } \\
\text { (participation in } \\
\text { leadership activities in } \\
\text { past year and in past } 3 \\
\text { years at high school, } \\
\text { self-assessment) }\end{array}$ \\
\hline Data & $\begin{array}{l}\text { British Skill Survey } 1997 \text { and } \\
2001 \text { (self-assessed importance } \\
\text { of job activities and key skills } \\
\text { at five-point scale; UK), } \\
\text { Qualification and Career } \\
\text { Survey 1979, 1985, } 1991 \text { and } \\
1998 \text { (self-assessed binary } \\
\text { indicator of presence of } \\
\text { particular tasks) and } \\
\text { Administrative Social Security } \\
\text { Records (Germany) }\end{array}$ & $\begin{array}{l}\text { Wisconsin Longitudinal Study } \\
1957-2005 \text { (senior high school } \\
\text { class); full-time male employees } \\
\text { only (USA) }\end{array}$ & $\begin{array}{l}\text { Project TALENT } \\
\text { 1960, National } \\
\text { Longitudinal Study of } \\
\text { the High School Class } \\
\text { 1972, High School and } \\
\text { Beyond 1982; white } \\
\text { male only (USA) }\end{array}$ \\
\hline $\begin{array}{l}\text { Dependent } \\
\text { variable }\end{array}$ & Log of wage & Log of hourly wage & $\begin{array}{l}\text { Log of annual earning } \\
\text { or hourly earnings } \\
\text { (depending on dataset); } \\
\text { 9-13 years after high } \\
\text { school graduation }\end{array}$ \\
\hline Results & $\begin{array}{l}\text { UK: One standard deviation } \\
\text { increase in directness relative } \\
\text { to caring was associated with } \\
\text { wage premium at level } 9.6 \% \text { in } \\
1997 \text { and } 10.8 \% \text { in } 2001 . \text { (One } \\
\text { standard deviation change in } \\
\text { the relative importance of } \\
\text { directness increased wages by } \\
15.6 \% \text { in the period 1997- } \\
2001 .) \\
\text { Germany: One standard } \\
\text { deviation increase in directness } \\
\text { relative to caring was } \\
\text { associated with wage premium } \\
\text { at level 3.8\% in 1979, 5.2\% in } \\
1985,8.5 \% \text { in 1991, and } 10.2 \% \\
\text { in 1998. (One standard } \\
\text { deviation increase in the } \\
\text { relative importance of direct- } \\
\text { ness raised wages by 19.8\% in } \\
\text { the period } 1979-1998 .)\end{array}$ & $\begin{array}{l}\text { One additional friendship } \\
\text { nomination of the person at high } \\
\text { school was associated with } 35 \% \\
\text { wage premium } 35 \text { years later }\end{array}$ & $\begin{array}{l}\text { Participation in both } \\
\text { captain and president } \\
\text { function was } \\
\text { connected with 3.8- } \\
22.1 \% \text { wage premium } \\
\text { (depending on dataset). } \\
3 \text { percentiles of people } \\
\text { with highest self- } \\
\text { assessment leadership } \\
\text { score had wages } \\
16.2-32.5 \% \text { higher } \\
\text { than others (depending } \\
\text { on dataset) }\end{array}$ \\
\hline $\begin{array}{l}\text { Other } \\
\text { regressors }\end{array}$ & $\begin{array}{l}\text { Gender, marital status, level of } \\
\text { education }\end{array}$ & $\begin{array}{l}\text { College-educated father, college- } \\
\text { educated mother, graduating class } \\
\text { size, proportion of students taking } \\
\text { math, proportion of students } \\
\text { taking a language, proportion of } \\
\text { students with college plans, } \\
\text { resident in Wisconsin, IQ, grade } \\
\text { rank, years of schooling, marital } \\
\text { status, social participation, number } \\
\text { of outings with friends, number of } \\
\text { outings with relatives, job found } \\
\text { through network, individual effect }\end{array}$ & $\begin{array}{l}\text { Educational } \\
\text { attainment, math score, } \\
\text { parents' education }\end{array}$ \\
\hline
\end{tabular}




\begin{tabular}{|c|c|c|c|}
\hline Study & Weinberger (2011) & Fortin (2008) & Dunifon, Duncan (1998) \\
\hline $\begin{array}{c}\text { Soft skill } \\
\text { variable(s) }\end{array}$ & $\begin{array}{l}\text { Leadership } \\
\text { (participation in } \\
\text { leadership activities in } \\
\text { past year at } \\
\text { high-school) } \\
\end{array}$ & $\begin{array}{l}\text { Motivation and work } \\
\text { effort } \\
\text { (importance of } \\
\text { money/work) }\end{array}$ & $\begin{array}{l}\text { Personal efficacy } \\
\text { (approximated by ability to reach } \\
\text { long-term goals) } \\
\text { Challenge vs. affiliation }\end{array}$ \\
\hline Data & $\begin{array}{l}\text { National Longitudinal } \\
\text { Study of the High } \\
\text { School Class 1972, } \\
\text { National Education } \\
\text { Longitudinal Study } \\
\text { 1988; white male only } \\
\text { (USA) }\end{array}$ & $\begin{array}{l}\text { National Longitudinal } \\
\text { Study of the High } \\
\text { School Class 1972, } \\
\text { National Educational } \\
\text { Longitudinal Study of } \\
\text { 1988/94; employed only } \\
\text { (USA) }\end{array}$ & $\begin{array}{l}\text { Panel Study of Income Dynamics; } \\
\text { men only (USA) }\end{array}$ \\
\hline $\begin{array}{l}\text { Dependent } \\
\text { variable }\end{array}$ & $\begin{array}{l}\text { Log of weekly earnings; } \\
7 \text { years after high school } \\
\text { graduation }\end{array}$ & Log of wage & Log of average hourly earnings \\
\hline Results & $\begin{array}{l}\text { Wage premium at level } \\
\text { of } 5.3 \% \text { in } 1979 \text { and } \\
11.5 \% \text { in } 1999 \text { was } \\
\text { estimated for aggregate } \\
\text { leadership variable. } \\
\text { Wage returns were } \\
\text { estimated as statistically } \\
\text { insignificant in } 1979 \text { and } \\
9.9 \% \text { in } 1999 \text { for } \\
\text { leadership in clubs, } \\
\text { performing arts, or } \\
\text { student publications, and } \\
4.0 \% \text { in } 1979 \text { and } 8.2 \% \\
\text { in } 1999 \text { for sport } \\
\text { participation }\end{array}$ & $\begin{array}{l}\text { Positive and increasing } \\
\text { impact of perceived } \\
\text { importance of } \\
\text { money/work on wage } \\
\text { (coefficient } 0.209 \text { at age } \\
25 \text { and } 0.258 \text { at age } 32 \\
\text { in NLS dataset and } \\
0.165 \text { at age } 24 \text { in NELS } \\
\text { dataset) }\end{array}$ & $\begin{array}{l}\text { One standard deviation increase in } \\
\text { personal efficacy (measured in 1972) } \\
\text { was associated with } \\
14 \% \text { wage premium in 1988-1992. } \\
\text { One standard deviation increase in } \\
\text { challenge relative to affiliation } \\
\text { (measured during years 1968-1972) } \\
\text { was associated with } 7 \% \text { wage } \\
\text { premium in 1988-1992. }\end{array}$ \\
\hline $\begin{array}{l}\text { Other } \\
\text { regressors }\end{array}$ & $\begin{array}{l}\text { Math score, interaction } \\
\text { terms } \\
\text { (baseline model) }\end{array}$ & $\begin{array}{l}\text { Importance of } \\
\text { people/family, self- } \\
\text { esteem, locus of control, } \\
\text { gender, high school } \\
\text { math score, education, } \\
\text { experience and tenure, } \\
\text { part-time employment, } \\
\text { black, married, child, } \\
\text { parental experience }\end{array}$ & $\begin{array}{l}\text { Years of education, sentence } \\
\text { completion test score, age, number } \\
\text { of siblings, years of education of } \\
\text { father, dummy variables for black, } \\
\text { father self-employed, father's } \\
\text { occupation, grew up in a city, grew } \\
\text { up in a town, grew up on a } \\
\text { farm/other area, grew up in the } \\
\text { South, family was poor growing up, } \\
\text { family was well-off, family was of } \\
\text { average income, health limits ability } \\
\text { to work in 1968-1971 }\end{array}$ \\
\hline
\end{tabular}




\begin{tabular}{|c|c|c|}
\hline Study & Semykina, Linz (2007) & Andrisani (1977) \\
\hline $\begin{array}{c}\text { Soft skill } \\
\text { variable(s) }\end{array}$ & $\begin{array}{l}\text { Challenge vs. affiliation } \\
\text { Initiative } \\
\text { (approximated by locus } \\
\text { of control) }\end{array}$ & $\begin{array}{l}\text { Initiative } \\
\text { (approximated by locus } \\
\text { of control) }\end{array}$ \\
\hline Data & $\begin{array}{l}\text { Russian Employee Survey 2000, } 2002 \text { and } \\
2003 \text { (Russia) }\end{array}$ & $\begin{array}{l}\text { National Longitudinal Study; men } 16-26 \\
\text { years in } 1968 \text { and } 48-62 \text { years in } 1969 \text { (USA) }\end{array}$ \\
\hline $\begin{array}{c}\text { Dependent } \\
\text { variable }\end{array}$ & Log of monthly earning & $\begin{array}{l}\text { Log of hourly } \\
\text { earnings }\end{array}$ \\
\hline Results & $\begin{array}{l}\text { One standard deviation increase in } \\
\text { challenge relative to affiliation was } \\
\text { associated with } 2.9 \% \text { wage premium } \\
\text { (significant at } 10 \% \text { level). Result was not } \\
\text { statistically significant separately for men } \\
\text { and } 3.2 \% \text { for women. } \\
\text { One standard deviation increase in internal } \\
\text { relative to external locus of control was } \\
\text { associated with } 7.9 \% \text { wage premium. The } \\
\text { same change would increase wages by } \\
4.6 \% \text { for men (significant at } 10 \% \text { level) and } \\
6.4 \% \text { for women. }\end{array}$ & $\begin{array}{l}\text { Young (older) white men, who were ,slightly } \\
\text { internal“ have enjoyed } 12 \%(8 \%) \text { wage } \\
\text { premium over comparable men who were } \\
\text { „slightly external”. }\end{array}$ \\
\hline $\begin{array}{c}\text { Other } \\
\text { regressors }\end{array}$ & $\begin{array}{l}\text { Age, age-squared, years of schooling, job } \\
\text { tenure, job tenure squared, dummy variable } \\
\text { for managers, number of job changes, } \\
\text { dummy for a recent unemployment } \\
\text { experience. }\end{array}$ & $\begin{array}{l}\text { Dummy variables for education, dummy } \\
\text { variable for completion of a formal } \\
\text { occupational training, tenure, potential work } \\
\text { experience, dummy variable for health, } \\
\text { married, residence in the South, degree of } \\
\text { urbanization in the local labour market }\end{array}$ \\
\hline
\end{tabular}

Source: Author.

Note: I) For US data defined as importance of the following job-tasks: adaptability in situations involving the interpretation of feelings, ideas or facts in terms of personal viewpoint; adaptability in influencing people in their opinions, attitudes or judgments about ideas or things; adaptability in dealing with people beyond giving and receiving instructions. For UK data defined as importance of planning job activities, knowledge about the organization and products, problem solving, noticing problems and (procedural) faults, and physical skills and work.

II) People skills index comprehends requirements on adaptability in dealing with people beyond giving and receiving instructions; adaptability in accepting responsibility for direction, control or planning of an activity; adaptability in influencing people in their opinions, attitudes or judgments about ideas or things; complexity at which worker performs a job in relation to people: mentoring, negotiating, instructing, supervising, diverting, persuading, speaking-signalling, serving, taking instructions.

III) Non-routine interactive consists of negotiating, lobbying, coordinating, organizing; teaching, training; selling, buying, advising customers, advertising; entertaining, presenting; employ, manage personnel. IV) Non-routine analytic tasks consist of researching, analysing, evaluating and planning; making plans, constructions, designing and sketching; working out rules and prescriptions; using and interpreting rules.

$V)$ Caring is needed to create cooperative environment, directness to communicate accurately. UK: Directness comprehends instructing, training or teaching people; making speeches or presentations; persuading or influencing others; and selling a product. Caring comprehends dealing with people; working in a team of people; counselling, advising or caring for customers; and listening carefully to colleagues. Germany: Directness comprehends negotiating, lobbying, coordinating and organizing; teaching or training; selling, buying, or advertising; and entertaining or presenting. Caring comprehends serving and accommodating; advising customers and clients; and helping out others. 
This brief overview showing relevancy of soft skills for wage determination can be supplemented with a note on their relation to recent development of gender wage gap. The above reviewed papers show that changes in employers' requirements on soft skills of employees, accompanied by relevant development of their wage returns, together with differences in distribution of these skills between genders led to a significant reduction of the gender wage gap. This conclusion is consistent with results of Bacolod, Blum (2008), Black, Spitz-Oener (2007) and Borghans, Weel and Weinberg (2006) in the case of soft skills, and Semykina, Linz (2007) and Fortin (2008) in the case of attitudes closely related to soft skills.

\section{Discussion on methodology}

Two different methodological approaches were used in overviewed papers for measuring soft skills. The direct one is based on questioning individuals on their behaviour (e.g. Weinberger, 2011; Kuhn, Weinberger, 2005) or their preferences and attitudes (e.g. Fortin, 2008; Semykina, Linz, 2007; Dunifon, Duncan, 1998; Andrisani, 1977). The indirect one approximates an individual's soft skills by job tasks (e.g. Bacolod, Blum, 2008; Borghans, Weel, Weinberg, 2008 and 2006; Black, Spitz-Oener, 2007), which are identified by trained experts (e.g. in case of Dictionary of Occupational Titles in USA) or by workers themselves (e.g. in case of British Skill Survey in UK or Qualification and Career Survey in Germany). It should be noted that the evidence, referred to by Borghans, Weel and Weinberg (2006), suggests that job tasks identified by workers and trained experts do not differ significantly.

Does the indirect approach measure soft skills reliably? The approximation of an individual's skills by job characteristics (regardless whether job tasks or skills requirements are taken into account) is based on an assumption that any job is performed only by workers with relevant skills. Since soft skills are closely related to attitudes (i.e. relatively stable learned predisposition to respond to certain things in a certain way) and thus their development is more difficult and slower than in the case of hard skills, it can be further assumed that only workers who already have relevant soft skills at required levels are hired (although they may lack some hard skills at the beginning, since these can be developed relatively easily and quickly). Under the second assumption, there is no problem with reverse causality in relation between soft skills and a job performed because the proper set of soft skills represents a condition for hiring. It should be noted that the mechanism described above does not influence the role of level and field of individual's education as the sorting device which is used for pre-selection of job applicants, because only those who have the education required are considered for the final selection based on soft skills. (This two-stage selection of workers based on education and subsequently on soft skills corresponds to the results of a European survey published in Balcar, Homolová, Karásek et al., 2011).

Relevancy of the assumption that jobs are performed by workers with relevant soft skills can be confirmed by the results of many empirical studies. The studies found a statistically significant match of individual's soft skills with job tasks (e.g. Weinberger, 2011; Borghans, Weel, Weinberg, 2008 and 2006) or at least with type of job (e.g. Kuhn, Weinberger, 2005, who match leadership skills with employment in managerial jobs). This evidence suggests that an indirect approach to soft skills measurement 
through job characteristics provides relevant data. Moreover, the usage of this approach can minimize the bias of data caused by subjectivity of individual's responses, improper questions or other factors present in case of direct questioning. On the other hand, the indirect approach is not capable of capturing differences among individuals, but only groups of individuals, i.e. individuals working in the same job.

The efficiency of indirect measurement of soft skills could be further improved by using methods of competence modelling, i.e. by using particular skills required for a job performance instead of widely used job tasks. However, the change of focus from job tasks to skills is not beneficial by itself. The main improvement consists in clear specification of levels of each skill by behavioural descriptors, enabling an accurate and objective description of a person suitable for a job. (The difference between job tasks and skills approaches can be illustrated by a job where communication on elementary level is very important, thus the importance of communication as a job task would be evaluated by high mark, while the required skill level by low mark. The results from these two approaches would be then significantly different.) Therefore, it is possible to state that for the purpose of estimating wage returns to particular skills, the approach based on competency modelling is more suitable.

\section{Conclusions}

There is a large number of factors which were found to be significant determinants of an individual's wage. Psychological traits, attitudes and soft skills represent factors, whose effect on individual's wages has begun to be examined recently. Today, there is an extensive empirical body on wage returns to the first two factors, but still a relatively small one on wage returns to soft skills. It can be caused by the fact that soft skills are hard to measure and so there is a lack of relevant data for its empirical examination.

Empirical papers focusing on soft skills use two different methodological approaches to measure them. The direct one is based on questioning individuals on their behaviour, preferences and attitudes, while the indirect one approximates individual's soft skills by job tasks identified by trained experts or by workers themselves. It can be noted that empirical evidences suggest that an indirect approach provides relevant data as well.

An overview of empirical literature on wage returns to soft skills, which can be found in this paper, shows that soft skills are connected with significant wage returns and contribute to closing of the gender wage gap. However, heterogeneity of approaches to specification and quantification of particular soft skills suggests that it is a field of empirical research with significant potential for further research (e.g. formulation of generally accepted definition of soft skills, an application of competence modelling tools for creating more relevant data for an analysis, estimation of returns to particular soft skills and not to their clusters etc.) 


\section{References}

ANDRISANI, P. J. (1977). Internal-External Attitudes, Personal Initiative, and the Labor Market Experience of Blackand White Men. The Journal of Human Resources, 12 (3). Pp. 308-328. DOI: 10.2307/145493

BACOLOD, M., BLUM, B. S. (2008). Two Sides of the Same Coin: U.S. "Residual" Inequality and the Gender Gap. Retrieved June 1, 2012, from http://www.rotman.utoronto.ca/bblum/personal/2\%20sides.pdf

BALCAR, J. (2012). Supply Side Wage Determinants: Overview of Empirical Literature. Review of Economic Perspectives, 12 (4). Pp 207-222. DOI: 10.7327/cerei.2011.03.01

BALCAR, J. (2011). Future skills needs in EU and skills transferability in 2020: Sector meta-analysis. ER - Central European Review of Economic Issues, 14 (1). Pp. 5-20.

BALCAR, J., HOMOLOVÁ, E., KARÁSEK, Z. et al. (2011). Transferable competences across economic sectors: Role and importance for Employment at European level. Luxembourg: Publications Office of the European Union. ISBN 97892-79-20946-8.

BLACK, S. E., SPITZ-OENER, A. (2007). Explaining Women's Success: Technological Change and the Skill Content of Women's Work.

Retrieved June 1, 2012, from http://ftp.iza.org/dp2803.pdf

BORGHANS, L., WEEL, B. ter, WEINBERG, B. A. (2008). Interpersonal Styles and Labor Market Outcomes. Journal of Human Resources, 43 (4). Pp. 815-858.

BORGHANS, L., WEEL, B. ter, WEINBERG, B. A. (2006). People People: Social Capital and the Labor-Market Outcomes of Underrepresented Groups.

Retrieved June 1, 2012, from http://www.nber.org/papers/w11985.pdf

CONTI, G., GALEOTTI, A., MUELlER, G., PUDNEY, S. (2009). Popularity. Retrieved June 1, 2012, from http://www.iser.essex.ac.uk/publications/working-papers/iser/2009-03.pdf

DUNIFON, R., DUNCAN, G. J. (1998). Long-Run Effects of Motivation on LaborMarket Success. Social Psychology Quarterly, 61 (1). Pp. 33-48.

FORTIN, N. M. (2008). The Gender m among Young Adults in the United States: The Importance of Money vs. People. Journal of Human Resources, 43 (4). Pp. 884-918. DOI: $10.1353 / \mathrm{jhr} .2008 .0006$

KUBEŠ, M., SPILLEROVÁ, D., KURNICKÝ, R. (2004). Manažerské competence. Praha: Gradiva Publishing. ISBN 80-247-0698-9.

KUHN, P., WEINBERGER, C. (2005). Leadership Skills and Wages. Journal of Labor Economics, 23 (3). Pp. 395-436. DOI: 10.1086/430282

MACHIN, S., MCINTOSH, S., VIGNOLES, A., VIITANEN, T. (2001). Basic Skills, Soft Skills and Labour Market Outcomes: Secondary Analysis of the National Child Development Study. Retrieved June 1, 2012, from https://www.education.gov.uk/publications/eOrderingDownload/RR250.pdf 
NSP (2011). Manuál pro tvorbu katalogu Národní soustavy povolání, určeno pro členy sektorových rad, expertních týmů a pracovních skupin, ver. 2. Retrieved June 1, 2012, from http://katalog.nsp.cz/Napoveda/Manual_pro_SR_NSP_II.pdf

REBER, A. S., REBER, E. (2001). The Penguin Dictionary of Psychology. London: Penguin Books. ISBN 0-14-051451-1.

SEMYKINA, A., LINZ, S. J. (2007). Gender differences in personality and earnings: Evidence from Russia. Journal of Economic Psychology, 28 (3). Pp. 387-410. DOI: 10.1016/j.joep.2006.05.004

STATT, D. A. (1998). The Concise Dictionary of Psychology. London: Routledge. ISBN 0-415-17939-4.

TURNER, Ch. F., MARTINEZ, D. C. (1977). Socioeconomic Achievement and the Machiavellian Personality. Sociometry, 40 (4). Pp. 325-336. DOI: 10.2307/3033481

WEINBERGER, C. (2011). The Increasing Complementarity between Cognitive and Social Skills, Retrieved June 1, 2012, from http://www.econ.ucsb.edu/ weinberg/MathSocialWeinberger.pdf 